UDC 378.147:001.895

DOI: $10.31470 / 2415-3729-2018-8-252-267$

\title{
Innovative Pedagogical Teaching Technologies: Content and Characteristics
}

\section{Chen Jing,}

postgraduate student of the department of general pedagogy and pedagogy of higher education

H. S. Skovoroda Kharkiv National Pedagogical University,

$\triangle 2$, Valentynivska Str., Kharkiv, Ukraine , 61000

E-mail:22273511@qq.com

ORCID: 0000-0001-6823-504X

Date of receipt of the article: August 03, 2018 Article accepted for publication: November 25, 2018

\section{Інноваційні педагогічні технології навчання: суть i характеристика}

\section{Чень Цзін}

аспірант кафедри загальної педагогіки та педагогіки вищої школи, Харківський національний педагогічний університет імені Г. С. Сковороди, $\checkmark$ вул. Валентинівська, 2, м. Харків, Україна, 61000

Дата надходження статті: 03 серпня 2018 р. Стаття прийнята до друку: 25 листопада 2018 р.

\section{Abstract}

The article is devoted to the problem of innovative pedagogical teaching technologies, implemented in the institutions of higher education, namely their content and characteristics. Analysing the problem, it was found that the term «educational technologies» is very common in science and education, and there are different approaches to its determination. The author of the article defines that «educational technologies» can be represented in three aspects, 
namely: scientific-methodological and descriptive, processual effective. It is noted in the article that, determining the structure of the category of «educational technologies», the scientists refer to its conceptual part, substantive, procedural and methodological and software support; they have singled out the basic methodological principles and criteria to be met by educational technologies. It is also noted in the article that the technical information technologies develop the idea of a programmed instruction associated with the unique capabilities of modern computers and telecommunications. The main goal of modern information technologies study is to prepare students for a full life in the informational society. The leading principles, as the basis for educational technologies introduction to higher educational institutions, are: the principle of orientation clearly and thoroughly defined goals; the principle of chosen training; the principle of subjectivity training; the principle of variability study; the pedagogical competence principle; the principle of professional similarities and borrowings; the principle of corresponding human nature. The author of the article defined that the methods of NIT training suppose: a traditional learning model; an alternative learning model. The modern educational technologies are discussed in the article and it gives the reason to believe that now they develop the idea of programmed study, which is associated with the unique capabilities of modern computers and telecommunications. The author of the article makes a conclusion that studies of many authors suggest that the main goal of modern information technology education is to prepare students for a full life in the information society. In author's opinion, the newest modern technologies are the technologies of mobile learning, based on the intensive use of modern mobile equipment and technologies.

Key words: institution of higher education, educational process, student, teacher, innovation, pedagogical technologies of training.

\section{References}

1. Bespalko, V. P. (1989). Slagaemyie pedagogicheskoy tehnologi [Constituents of pedagogical technology]. Moskva: Prosveschenie [in Russian].

2. Burkova, L. (2001). Tekhnolohii v osviti [Technologies in education] Ridna shkola - Native School, 2, 18-19 [in Ukrainian]. 
3. Vitvytska, S. S. (2006). Osnovy pedahohiky vyshchoi shkoly [Basics of higher school pedagogics]. Kyiv: Tsentr navchalnoi literatury [in Ukrainian]

4. Zhernovnikova, O. A (2016). Mikrotekhnolohiia vyvchennia haluzi «Matematyka» [Microtechnologies of studying the field of «Mathematics»]. Kharkiv: Mitra [in Ukrainian].

5. Ziaziun, I. A. (2001). Tekhnolohizatsiia osvity yak istorychna neperervnist [Education technology as a historical continuity]. Neperervna profesiina osvita: teoriia $i$ praktyka Continuing professional education: theory and practice, 11, 73-85 [in Ukrainian].

6. Lozova, V. I. (Ed.). (2005). Lektsii z pedahohiky vyshchoi shkoly [Lectures on Higher School Pedagogics]. Kharkiv: «OVZ» [in Ukrainian].

7. Lozova, V. I. (Ed.). (2000). Tsilisnyi pidkhid do formuvannia piznavalnoi aktyvnosti shkoliariv [Holistic approach to forming a cognitive activity of pupils]. Kharkiv: «OVS».

8. Okomkov, O. P. (1994). Sovremennyie tehnologii obucheniya v vuze: ih suschnost, printsipyi proektirovaniya, tendentsii razvitiya: ih suschnost, printsipyi proektirovaniya, tendentsii razvitiya [Modern educational technologies in higher educational institutions]. Vyisshee obrazovanie $v$ Rossii - Higher education in Russia, 2, 17-21 [in Russian].

9. Sazonenko, H. S (Ed.). (2000). Perspektyvni osvitni tekhnolohii [Perspective main technologies]. Kyiv: Hopak [in Ukrainian].

10. Savelev, A. Ya. (1994). Tehnologii obucheniya i ih rol v reforme vyisshego obrazovaniya [Educational technologies and their role in the higher education reform]. Vyisshee obrazovanie $v$ Rossii Higher education in Russia, 2, 29-37 [in Russian].

11. Selevko, G. K. (1998). Obrazovatelnyie tehnologi [Educational technologies]. Moskva: Narodnoe obrazovanie [in Russian].

12. Sokolov, V. N. (1995). Pedagogicheskaya evristika [Pedagogical heuristics]. Moskva [in Russian]. 


\section{Introduction}

The ideal modern teaching personality is not developed by an encyclopaedic memory, but with a flexible mind, with rapid response to all new, with full, well-developed knowledge and needs for further independent activity, with good indicative skills and creative abilities.

«One of the most serious shortcomings of our school practice that teaching children is mainly a teacher» - this opinion by V. Sukhomlynskyi is applicable to the characteristics of the today educational process.

The development of the student's creative potential is treated today as the main task of higher education. To implement it, we must firstly consider a student not as a sum of external influences, but as a coherent, active substance. It is in it the main content of the restructuring of the educational process. A student is not the object, but foremost the creator of its own «Self».

Consequently, the learning process should be built to promote the conscious participation of a person who studies a discipline.

To decide these urgent problems is only possible through the extensive introduction of new educational technologies aimed at student's comprehensive development.

Education with innovative technologies is more effective than a classical one. It integrates processes that should not be combined within a classical education, training, career planning, continuous education. As you can see, research on the use of educational technology last long, but, on our opinion, but not disclose modern educational technologies, and their classification.

Different pedagogical technologies have been studied out by V. P. Bespalko, M. V. Klarin, O. P. Okomkov, O. M. Pyekhota, S. O. Sysoyeva and others. Many studies are devoted to problems and goals of modern educational technologies.

The article represents the scientific analysis of existing educational technologies used in the educational process.

\section{Materials and Methods}

A number of scientific search methods were used for the research, in particular - analysis, synthesis, generalization and systematization of scientific literature. 


\section{Results and Discussion}

The study was conducted as a part of the comprehensive program of research department of theory and methodology of professional education at H. S. Skovoroda Kharkiv National Pedagogical University «Improving the effectiveness of the educational process in secondary and higher education» (LC number 200199004104). During the research the following methods were used: theoretical analysis of the problems' sources and expertize of electronic educational resources, results' synthesis and evaluation.

Analysis of the category of «educational technology» shows that its structure includes:

- a conceptual part (a brief description of ideas, hypotheses, principles that help its understanding);

- a content (learning objectives, scope and nature of educational content);

- a procedural part - production process (organization of educational process, methods of students' learning, methods and forms for the diagnostics of teachers' training process);

- a software and methodological support (curricula and programs, teaching and learning aids, learning tools and diagnostics).

There are the following features of educational technologies: submitting content material in the form of educational problems; a clear logic, actions and operations sequences; providing motivational activities; availability of means and methods of obtaining information; development of technology and its use requires creativity of teachers and students; each individual link technology achieves planned results only by relying on psychological grounds.

Educational technology does not provide the same high level of all students' educability and education; the outcome is influenced by many factors: the level of teacher's pedagogical skills, intellectual and emotional background of the group, the institution's material base and other.

It's more useful to consider the basic criteria of educational technologies: a conceptuality (relying on a concept that includes philosophical, psychological, educational, social and pedagogical justification educational purposes); systematic (educational technology with all the features of a system) and logic process (the relationship 
of all its parts, integrity); a controllability (the ability of planning goals, projecting learning, diagnosing by various means and methods with the purpose of results' correcting); an efficiency (an optimal cost, a guaranteed achieving of the intended result - a certain standard of education); a reproducibility (a possibility of other similar conditions).

The sources and components of new educational technologies are: social transformation and new pedagogical thinking; social, educational, psychological science; modern advanced teaching experience; historical domestic and foreign experience (heritage of previous generations); folk pedagogy (Bespalko, 1989).

The leading principles, which are subject of educational technologies, include:

- the principle of orientation clearly and thoroughly defined goals (the objectives' formulation is in the following forms: through the contents of an object or its parts, through the teacher's work, because of internal processes and changes in the students' development, expressed outwardly through training activities);

- the principle of chosen training - a didactic choice (the principle of implementing the students' right for a didactic choice freedom in establishing the sense of real and equal partners of that measure being fully aware of the responsibility for your choice);

- the principle of subjective training (an individual subjectivity (personality) appears in integrating and evaluating facts, events of reality based on personal values and significant internal guidelines, which should help the individual to know yourself, selfdetermination and self-realization, but not predetermined shape properties);

- the principle of studying a variability (it requires original and new pedagogical impact on students' perception. While in the subject - with a student, constantly changing, a teacher should be able to naturally and organically change its own position according to a new situation, providing a dynamic learning process);

- the principle of pedagogical competence (it dictates the optimal ratio of different types of students' work (training, employment, social activity, sport, art), gaming and non-gaming, traditional and original forms of educational work, mind and emotions of teachers in student life, providing educational measure); 
- the principle of professional similarities and borrowings (it demonstrates the close relationship of educational technology to other types of persons' activities (theater, rhetorics, psychotherapy, social psychology, aesthetics), requiring mandatory teaching professional interpretation of borrowings to convert them into actual pedagogical tools);

- the principle of corresponding a human nature (this means building a learning process that best meets the natural mechanisms of assimilation of social experience and provides students the possibility of developing their intellectual capacities).

Thus, the structure of the category of «educational technology» includes: a conceptual part, a substantive, a procedural and software and methodological support. And also it's possible to identify the basic methodological principles and criteria to be met by educational technology.

In the work by I. Prokopenko, it is the structure of educational technology and system-relations of its elements, which consists of the following units:

The first block - an educational task: students, learning objectives, learning content.

This block defines the goal the achievement of which is due to the situation (conditions) and the information (content), which students practise in their work.

The second unit - a technology of education: teachers, educational process, organizational learning.

This block opens the appropriate educational technologies, which ensured the integrity of coupling components: an educational process, carried out in certain organizational forms, the choice of which depends on the teacher's skills.

Thus, the constituent elements of educational technology include two units: students, learning objectives, learning content; teachers, educational process, organizational learning.

It is possible to identify the following groups (types) of educational technology, within which the particular types of technology could be defined:

I. The pedagogical technologies for target orientation:

- the level of use (a general technology, a subject specialization technology, a module-rating technology); 
- the consideration of students' controllableness (a gifted education technology, a technology of working with «difficult» students, a mass technology, an advanced technology of education, etc.);

- the direction of traditional education modernization (based revitalization, based on the intensification of activities, based on the performance of education, a copyright technology based on humanization and democratization of relations, based on new didactic and methodological organization (reconstruction) materials, an alternative one);

- the nature of the content (teaching and educating, general and professional, humanistic and technocratic).

II. Teaching technology in nature relationship of a teacher and a student:

- according to learners (an authoritarian technology, a centered technology, a technology of cooperation, a technology of free education, an esoteric technology).

III. Pedagogical technologies by means of training:

- the organizational forms (lectures and seminars, and alternative, individual, group, collective, in pairs, academic and club (of interest), individual and differentiated learning);

- the dominant means (dogmatic, reproductive, explanatory, illustrative, software, problem, dialogue, developing education, flexible learning technologies, gaming technology, self-development training, computer technology);

- the type of control of cognitive activities (by V. Bespalko) (lecture classical learning, learning through audiovisual TMT, the system of «adviser»; learning through textbooks, the system of «small groups» - group, differentiated teaching methods, computer training, the system of «tutor» - individual training, «training program», for which there are pre-compiled programs) (Bespalko, 1989);

- the focus on the personality's structure (information technology - designed to build knowledge and skills; operational aimed at creating ways of learning activities, self-formation mechanisms of self-identity, heuristics - the development of creative skills) (Vitvytska, 2006). 
Among the educational technologies there are such following groups: educational technologies for the target orientation, educational technologies for the nature of the relationship of a teacher and a student, educational technologies by means of training (Savelev, 1994; Sokolov, 1995).

«New information technology (NIT)» - a set of methods and technical means of collection, organization, preservation, processing, transmission and presentation of information through computers and computer telecommunications (Zhernovnikova, 2016; Ziaziun, 2001).

Pedagogy determines NIT as a training methodology and technology of the educational process using the latest e-learning, and especially computers.

The components of NIT training are NIT training means and way of their using in a classroom.

The NIT training means are:

- hardware (classes teaching computers, local and global educational computer networks, electronic equipment demonstration.)

- software and methodology (software and methodological tools, computer courses, instructional software and systems);

- teaching (teaching manuals, specifications and technical documentation, organizational and instructional materials).

The methods of NIT training suppose: a traditional learning model (fragmented computer use in the classroom or as a trainer for demonstration, monitoring and testing knowledge, scientific and research work of students); an alternative learning model (a research work in computer laboratories, computational experiments, telecommunication projects educational, distance learning) (Okomkov, 1994).

«Technical Information Technology» - a process of preparation and transmission of information by means of a computer and other hardware. They develop the idea of programmed instruction and open really new, yet unexplored options for training related to the unique capabilities of modern computers and telecommunications (Sazonenko, 2000; Selevko, 1998).

Computer technologies aimed at: preparation of individual information society; formation of skills to work with information; develop communication skills; formation of research skills and 
abilities of the selection of optimal solutions; providing a large amount of qualitative information (Selevko, 1998).

Computer technology can be implemented in the following three ways:

- technology as a «penetration» (the use of computer-based training on selected topics chapters);

- as a major (using the study of basic topics);

- as mono technology (when the whole learning process: diagnosis, management, monitoring carried out by a computer).

The conceptual provisions of computer technology are:

- training - communication with the computer;

- adapting the computer to student's individual characteristics (the principle of adaptability);

- interactive nature of learning;

- manageability and the instructor of the learning process;

- providing students interact with the computer for all types: subject, object, subject-object, object-subject;

- optimal combining of individual and group work;

- creating a psychological comfort in the communication with a computer;

- unlimited learning: content, its interpretation and application;

- computer technology based with some formal content model, which is represented by software recorded in computer memory and capabilities of telecommunication network.

The computer serves as: a teacher; the sources of educational information; a visibility; a personal information space; a simulator; a diagnostic and control tool; working tool, because it serves as a means of word processing and conservation; a text editor; a graphic editor; a computer; a modelling tool.

A teacher of computer technology has the following features:

- the organization of educational process at the level of subject groups;

- the organization of intra-group activity and coordination;

- observing particular students, providing their assistance;

- individual training;

- preparing of information environment components (Lozova, 2005; Lozova, 2000). 
Consequently, technical information technologies develop the idea of a programmed instruction associated with the unique capabilities of modern computers and telecommunications. The main purpose of NIT education is to prepare students for a full life in the information society.

Modern technologies include the following types of learning:

- a dogmatic learning (It is based on dogmatic learning a way of studying facts and phenomena of reality as certain immutable provisions (dogmas) without practice, human experience; a dogmatic learning teaches memorization to learners, their mechanical reproduction of finished phrases, quotes, strange thoughts, that to some extent contributes to the development of mechanical storage instead of individual intellectual capabilities, their independence);

- an explanatory learning (Its main purpose is to provide a system of mastering the subjects of scientific knowledge, mastering skills. It cannot be communicated to existing knowledge, and they explain, justify, comment, that they made no rote memorization and there is the understanding of what the individual's mental activity needs. The «chain», as the application of knowledge, is appeared in this type of training. Therefore, the important place is occupied by an self-study work, tasks, exercises, translations, preparation of charts, tables etc. However, there is a big amount of works for a prepared sample. So an explanatory view is related to a training material explaining the extensive visuals' use and reproductive nature of learning for teachers);

- a problem learning (It is the organization of the learning process, the foundation of which is a formation of the educational process under problem situations, identifying students' problems and their solving by themselves or with the help of the teacher. So, the main tasks of a problem-based learning are: the development of thinking skills of an individual, its creative skills, bringing up active creative persons who are able to see, ask and solve non-standard problems, and the individuals' assimilation of knowledge, skills, acquired during an active cognitive activity);

- a modular learning (Its each substantive module includes the following components: a target - the purpose and objectives of the study of a particular module, a content - the content's basic 
units, terms, concepts, laws as the essence of a particular section of the discipline, an operational component - the definition of cognitive skills that should be mastered by student, a methodical component it provides advice, tips for self-study work in learning; a control - it presents questions, assignments, tests to check the level of learning. The results of the study of each module's unit are reflected in the scores gaining by a student. Therefore, a student itself may determine the degree of learning. Thus, modular learning is associated with a ranking system control. The larger and more complex is a module, then the more points it receives);

- a distance learning (A distance learning provides a spatial distance learning of subjects which interact with each other via telecommunications. This type of learning is built on the use of computer technologies. It allows to access the world and scientific treasures from anywhere, which has an access to the Internet in order to communicate with teachers, professionals, peers from other cities, universities, to consult with experts, to choose the system of training, content, forms, methods, to be simultaneously in different virtual classes, to choose a pace of learning, its intensity in different educational industries, both studying in various educational institutions, have the opportunity in the process of mastering educational material to ask questions, get answers, participate in contests, competitions, which are held in different cities and countries. The simultaneous participation in the Olympiad large number of students from different cities has the effect of their creative union and the general cooperation; demonstrates their personal activities to see their work published online, to become authors of scientific, literary or other works and so on. When a student publishes their work online, he/she declares in such a way its authorship of scientific, artistic or other work, which has the ability of self-expressing and self-asserting, solving the psychological problems associated with a direct communication);

- a personality-oriented learning (a student-centred learning comes from the definition of identity, self-worth of each person, which requires a software development and a self-identity, based on the unique identification of individual subjective experience, abilities, interests, values, opportunities to self-realization in knowledge, training activities, behaviour); 
- a developing learning (It is the orientation of the educational process' contents, principles, methods and forms on the development potential of a person, its intellectual, sensual, volition sphere. The main task of a teacher in the process of a developing training is organizing the educational activities subject aimed at developing its mental abilities, cognitive activity, independence, cognitive interests. A developing training, that is based on the students' study and search activities, presupposes group or collective forms of work, providing the critical comparison of different approaches, the clash of different points of view, etc.);

- a mobile learning (It is the new technology learning based on the intensive use of modern mobile equipment and technologies. It is closely linked to educational mobility in the sense that students should be able to participate in educational activities without restrictions in time and space. The use of mobile technology opens up new opportunities for learning, especially for those who lives in isolation or in remote places or faces difficulties in learning. The ability to study anywhere and anytime, which is the characteristic of a mobile learning today, is the general trend of life intensification in the informational society).

\section{Conclusions}

So, the article discussed modern educational technologies gives a reason to believe that it is developed the idea of programmed instruction, which is associated with the unique capabilities of modern computers and telecommunications. Studies of many authors suggest that the main goal of modern information technology education is to prepare students for a full life in the information society. The newest modern technologies are the technologies of mobile learning, based on the intensive use of modern mobile equipment and technologies.

\section{Чень Цзін}

\section{Інноваційні педагогічні технології навчання: суть i характеристика}




\section{Анотація}

В статті розглянуто інноваційні педагогічні технології навчання, які упроваджуються у закладах вищої освіти, а саме їх суть і характеристика. Проаналізувавши проблему, автором статті було виявлено, що термін «освітні технології» дуже поширений в науці і освіті, а також й те, що існують різні підходи до його визначення. Автор зазначає, що «освітні технології» можуть бути представлені в трьох аспектах, а саме: науково-методичному та описовому, процесуальному ефективному. Визначаючи структуру категорії «освітні технології», науковець посилається на iі: концептуальну частину, матеріальну, процедурну та методичну та програмну підтримку; виокремивши основні методологічні принципи та критерії, якими повинні відповідати освітні технології. У статті автором відзначається, що технічні інформаційні технології розробляють ідею запрограмованої інструкції, пов'язаної 3 унікальними можливостями сучасних комп’ютерів і телекомунікацій. На думку автора статті, основною метою сучасного навчання інформаційних технологій є підготовка студентів до повноцінного життя в інформаційному суспільстві. До провідних принципів, які є підгрунтям упровадження освітніх технологій у закладах вищої освіти, автор статті відносить: принцип орієнтації чітко та грунтовно визначених цілей; принцип обраної підготовки; принцип навчання суб'єктивності; принцип дослідження мінливості; принцип педагогічної компетентності; принцип професійної схожості та запозичень; принцип відповідної людської природи. У статті обговорюються сучасні освітні технології, що дають підстави вважати, що зараз вони розвивають ідею програмованого навчання, яке пов'язане 3 унікальними можливостями сучасних комп'ютерів i телекомунікацій. Дослідження багатьох науковців свідчать про те, що головною метою сучасного навчання інформаційних технологій є підготовка студентів до повноцінного життя в інформаційному суспільстві. Автор статті робить висновок, що новітніми сучасними технологіями $є$ технології мобільного навчання, що грунтуються на інтенсивному використанні сучасного мобільного обладнання та технологій. 
Ключові слова: заклад вищої освіти, освітній процес, студент, викладач, інновація, педагогічні технології навчання.

\section{Чень Цзин}

\section{Инновационные педагогические технологии обучения: сущность и характеристики}

\section{Аннотация}

В статье рассмотрены инновационные педагогические технологии обучения, внедряющиеся в учреждениях высшего образования, а именно их суть и характеристика. Проанализировав проблему, автором статьи было выявлено, что термин «образовательные технологии» очень распространен в науке и образовании, а также и то, что существуют различные подходы к его определению. Автор отмечает, что «образовательные технологии» могут быть представлены в трех аспектах, а именно: научно-методическом и описательном, процессуальном эффективном. Определяя структуру категории «образовательные технологии», ученый ссылается на ее: концептуальную часть, материальную, процедурную и методическую и программную поддержку; выделив основные методологические принципы и критерии, которыми должны соответствовать образовательные технологии. В статье автором отмечается, что технические информационные технологии разрабатывают идею запрограммированной инструкции, связанной с уникальными возможностями современных компьютеров и телекоммуникаций. По мнению автора статьи, основной целью современного обучения информационных технологий является подготовка студентов к полноценной жизни в информационном обществе. К ведущим принципам, которые являются основой внедрения образовательных технологий в учреждениях высшего образования, автор статьи относит: принцип ориентации четко и основательно определенных целей; принцип выбранной подготовки; принцип обучения субъективности; принцип исследования изменчивости; принцип педагогической 
компетентности; принцип профессионального сходства и заимствований; принцип соответствующей человеческой природы. В статье обсуждаются современные образовательные технологии, которые дают основания полагать, что сейчас они развивают идею программированного обучения, которое связано с уникальными возможностями современных компьютеров и телекоммуникаций. Исследования многих ученых свидетельствуют о том, что главной целью современного обучения информационных технологий является подготовка студентов к полноценной жизни в информационном обществе. Автор статьи делает вывод, что новейшими современными технологиями являются технологии мобильного обучения, основанные на интенсивном использовании современного мобильного оборудования и технологий.

Ключовые слова: вуз, учебный процесс, студент, преподаватель, инновация, педагогические технологии обучения. 